Article

\title{
Fruit Yield and Quality of 'Valencia' Orange Trees under Long-Term Partial Rootzone Drying
}

\author{
Amr Mossad ${ }^{1}$, Vittorio Farina ${ }^{2}\left[\right.$ and Riccardo Lo Bianco ${ }^{2, *(1)}$ \\ 1 Agricultural Engineering Department, Ain Shams University, Cairo 11241, Egypt; \\ amr_abdelbari@agr.asu.edu.eg \\ 2 Department of Agricultural, Food and Forest Sciences, University of Palermo, 90133 Palermo, Italy; \\ vittorio.farina@unipa.it \\ * Correspondence: riccardo.lobianco@unipa.it; Tel.: +39-091-238-96097
}

Received: 30 December 2019; Accepted: 22 January 2020; Published: 23 January 2020

\begin{abstract}
Climate, soil and tree water status, fruit yields and quality of 'Valencia' orange trees were monitored over five consecutive seasons (2007-2012) to study the effects of irrigation placement or volume. Three irrigation treatments were imposed: conventional irrigation (CI, 100\% of crop evapotranspiration on both sides of the rootzone), partial rootzone drying (PRD, $50 \%$ of CI water only on one alternated side of the rootzone) and continuous deficit irrigation (DI, $50 \%$ of CI water on both sides of the rootzone). Yield parameters were generally not affected by PRD, and only yield per tree was lower in DI than CI trees. Fruit size and juice content were also reduced by DI, and not by PRD. Both PRD and DI increased juice soluble solids and acidity, vitamin C and carotenoid concentrations, as well as fruit, juice and sugar productivity per unit of irrigation water. Overall, the straight reduction of irrigation volumes by $~ 55 \%$ (DI) induced an average of $4.4 \%$ leaf dehydration, which caused significant fruit size reductions and a 3.4\% reduction in juice yield, corresponding to a loss of about 2.6 tons of juice and $261 \mathrm{~kg}$ of sugars per hectare and year. On the other hand, water savings of about 2 mega liters per hectare and year with PRD caused a mild 2.3\% leaf dehydration and mainly fruit quality improvements, indicating that PRD is a sustainable irrigation strategy for 'Valencia' orange.
\end{abstract}

Keywords: carotenoids; citrus; deficit irrigation; fruit development; juice yield; soluble solids; vitamin C; water productivity

\section{Introduction}

Cultivation of fruit trees in semi-arid regions of the Mediterranean is often characterized by high evapotranspirative demand by the atmosphere and limited water availability in the soil. For these reasons, exploiting novel irrigation strategies that can maximize crop water use efficiency is crucial for citrus fruit production.

In fruit trees, regulated deficit irrigation (RDI) has proved to be a powerful tool to reduce shoot growth, improve fruit quality, and save irrigation water by imposing moderate levels of plant water stress during specific stages of crop development [1,2]. Results of RDI experiments have been promising in certain regions and for some fruit crops, such as peach [3-6], pear [7-9], French prune [10], almond [11-13], pistachio [14-16], apricot [10,17], and olive [18-20]. In citrus, yield is often proportional to vegetative growth, which makes the control and regulation of water deficit quite complex. Indeed, RDI studies have often documented significant fruit drop or reduced final fruit size and yields, depending on the severity or period of deficit imposition [21-23]. On the other hand, long-term RDI studies have reported increased water use efficiency in oranges [24,25]. Despite some encouraging results, RDI remains a complex management practice for most farmers as it tightly depends on climate variables and relies on precise and expensive tree water status measurements. 
Partial rootzone drying (PRD) is an irrigation technique that was originally developed for grapes in Australia, with the primary aim of reducing the amount of water used for irrigation [26,27]. With PRD, only one half of the rootzone is irrigated, whereas the other half is exposed to drying soil. This induces roots to produce abscisic acid (ABA), which is translocated to the shoots, inducing partial stomatal closure, and ultimately increased water use efficiency [26]. The irrigated half of the rootzone allows for adequate levels of plant water potential [28] and satisfactory rates of the metabolic and physiological processes associated with water stress [26,29]. The technique relies on cyclical wetting and drying of parts of the rootzone in order to maintain root-derived ABA signals [30].

The impact of PRD has been extensively investigated in grapevines [29,31-33] and, to a lesser extent, in other woody perennials (e.g., olive [34] and apple [35]). In citrus, water savings by PRD have generated contrasting results. In particular, some PRD studies show reduced tree growth, fruit size and yield in response to insufficient amounts of water [23,36-38]. Other PRD works suggest that yields and crop loads can be maintained to control levels in orange, grapefruit and lemon trees [39-42].

Size, rind appearance, and internal maturity are the major quality parameters for citrus fruit, and these variables are strongly influenced by irrigation management [43]. Sensitivity to water deficit may vary according to phenological stages, and can be managed to improve fruit quality [44,45]. If water deficit is applied during stage II of development (fruit growth by cell enlargement), a subsequent rehydration due to winter rainfall may result in no significant changes of final fruit size [46]. Reducing water supply during the initial and final stage of fruit development will delay size increases in lemons, despite the final yield being unaffected [47]. Reduced water supply, particularly during late fruit development, is associated with higher total soluble solids and titratable acidity, and reduced juice content [21,48-51]. Recently, it has been shown that deficit irrigation increases flavonoid content in the juice of 'Valencia' oranges [52].

However, the use of PRD in late-ripening 'Valencia' orange trees, and specifically its effect on fruit and juice quality, has not been extensively investigated as there is a lack of understanding of fruit quality modifications in response to seasonal drought stress. Data presented in this study are part of a long-term project on deficit irrigation in 'Valencia' orange. Results of physiological parameters measured on the same trees under the same treatments were reported in Mossad et al. [53]. The objectives of the present study was to determine the yield and fruit quality responses of 'Valencia' orange trees to long-term PRD and continuous deficit irrigation under typical Mediterranean field conditions.

\section{Materials and Methods}

\subsection{Experimental Site}

The experiment was performed in an experimental plot of the Department of Agricultural, Food and Forest Sciences, University of Palermo, Italy (30.06N, 13.21E, and $31 \mathrm{~m}$ a.s.l.) using adult orange trees (Citrus sinensis, cv Valencia). The trees were grafted onto sour orange (Citrus aurantium, L.) rootstock, spaced at $4 \times 4 \mathrm{~m}$, and trained to a raised ( $0.8 \mathrm{~m}$ from the ground) globe canopy reaching 2.5-3 $\mathrm{m}$ in height. The study considered five crop seasons starting in spring 2007 and ending with the harvest of the fifth crop in spring 2012. Typically, the 'Valencia' orange trees at the experimental site bloom in the month of April and produce mature fruits after $380-400$ days. The soil was a loam (52\% sand, $29.1 \%$ silt, and $18.9 \%$ clay) with $0.239 \mathrm{~m}^{3} \mathrm{~m}^{-3}$ water content and $-12.9 \mathrm{kPa}$ water potential at field capacity (FC).

All trees were equally fertilized with complex solid fertilizers (11N:22P:16K at the rate of $1.5 \mathrm{~kg} /$ tree) once a year in winter and soil was regularly tilled to control weeds. Irrigation was provided by a single line per tree row and two micro-sprinklers per tree located at about $1 \mathrm{~m}$ from the trunk and $0.5 \mathrm{~m}$ from the ground. Micro-sprinklers with $360^{\circ}$ circular spray pattern and delivery rates of $183 \mathrm{~L} \mathrm{~h}^{-1}$ (2-mm diam) and $386 \mathrm{~L} \mathrm{~h}^{-1}$ (3-mm diam) were connected to PVC lines using 5-mm diameter polyethylene tubing of various length and wood sticks to switch the portion of rootzone to be irrigated. 


\subsection{Irrigation Treatments and Experimental Design}

In June of each year, three irrigation treatments were imposed, (1) control irrigation (CI), delivering $100 \%$ of crop evapotranspiration $\left(\mathrm{ET}_{\mathrm{c}}\right.$ ) on the entire rootzone with two 3-mm-diameter sprinklers per tree; (2) partial rootzone drying (PRD), delivering about $50 \%$ of CI water only on one alternated side of the rootzone with one 3-mm-diameter sprinkler per tree; (3) continuous deficit irrigation (DI), delivering about $50 \%$ of $\mathrm{CI}$ water on the entire rootzone with two 2 -mm-diameter emitters per tree. Interval (1-5 days) and duration (40-120 $\mathrm{min}$ ) of irrigation events were adjusted to maintain soil moisture above $80 \%$ of field capacity $(-50 \mathrm{kPa})$ in the rootzone of $\mathrm{CI}$ trees, while avoiding wetting of the dry sides of PRD trees. In PRD trees, the wet and dry sides of the rootzone were switched every $2-3$ weeks when soil water potential in the dry side reached approximately $-150 \mathrm{kPa}$. The experimental design included four random blocks, each with four trees per irrigation treatment, for a total of 48 trees of similar size.

\subsection{Soil, Plant and Atmosphere Water Status}

Weather parameters were recorded continuously with two $\mu$ Metos stations (Pessl Instruments, Austria) located in the experimental plot. Data were used to calculate daily reference evapotranspiration $\left(\mathrm{ET}_{0}\right)$ according to the FAO Penman-Monteith equation. Daily $\mathrm{ET}_{\mathrm{C}}$ was determined using a $\mathrm{K}_{\mathrm{c}}$ set to 0.7 from October through May and to 0.65 from June through September, due to the specific soil management, weather conditions and the long 'Valencia' fruit growth period [54].

Twelve Watermark sensors (Irrometer Co., Riverside, CA, USA) directly connected to the weather station were positioned at about $80 \mathrm{~cm}$ from the sprinklers, $1 \mathrm{~m}$ from the tree trunk and at a depth of $45 \mathrm{~cm}$, and used to monitor soil water potential (SWP).

Leaf relative water content (RWC) was monitored every two weeks during the irrigation period and at longer intervals during rainy periods. It was estimated as $[(\mathrm{FW}-\mathrm{DW}) /(\mathrm{TW}-\mathrm{DW})] \times 100$, where FW is the leaf fresh weight, TW is the leaf weight at full turgor, and DW is the leaf dry weight.

\subsection{Yield and Fruit Quality}

Each year, harvest time was determined by monitoring sugar and acid content, and fruits were harvested in 2-3 picks within the first three weeks of May. The fruits of each tree were weighed and counted directly in the field. Trunk circumference was also measured above the graft union each year before harvest and trunk cross-sectional area (TCSA) was used to calculate yield efficiency (kg of fruit per $\mathrm{cm}^{2} \mathrm{TCSA}$ ) and cropping efficiency (number of fruits per $\mathrm{cm}^{2} \mathrm{TCSA}$ ).

At every pick date, a sub-sample of 10 fruits were collected randomly from each tree and brought to the laboratory. In the laboratory, each fruit was weighed, measured in height and width, and photographed with a Nikon Coolpix L10 digital camera under controlled light conditions. Digital images were used to determine the intensity of the peel color in each fruit using an algorithm developed with MATLAB ${ }^{\circledR}$ software (The MathWorks Inc., Natick, MA, USA) that converts images from RGB to CIE $1976 \mathrm{~L}^{*} \mathrm{a}^{*} \mathrm{~b}$ format, extracts the fruit from the image (removing the image background) and quantifies color characteristics as the weighted distance of each pixel in the image from a reference sample (best colored area interactively chosen from a well-colored fruit). The output is an index ranging from 0 (no orange) to 1 (full orange).

The juice was extracted from each fruit with a reamer juicer and weighed to determine juice yield as a percentage of total fruit weight. Total soluble solids (TSS) were measured in the juice of each fruit using a digital refractometer (Atago Co., Ltd., Tokyo, Japan). Juice $\mathrm{pH}$ and titratable acidity were determined using a compact titrator (Crison Instruments, SA, Barcelona, Spain) and acidity was expressed as grams of citric acid per $100 \mathrm{ml}$ of juice. All measurements were performed at room temperature. Juice water content was also measured by evaporating pre-weighed amounts of juice at $60^{\circ} \mathrm{C}$. 
Only in 2010, total carotenoid and vitamin C contents in the juice were also measured. Vitamin $C$ was determined as the amount of ascorbic acid using a L-ascorbic acid test kit (Boehringer Mannheim-R-Biopharm, Roche, Germany), according to the manufacturer's protocol. Total carotenoids were determined by UV-visible spectrophotometry using a Beckman DU-640 spectrophotometer (Beckman Coulter, Inc., CA, USA) as described in Arena et al. [55].

\subsection{Leaf Nutrients}

During the 2010-2011 cropping season, leaf nutrient level was determined by foliar analysis. For this purpose, six-month-old leaves were collected from the mid portion of four representative non-bearing shoots (one on each side of the canopy) from each tree in the trial. Leaves were sampled five times on 15 June, 7 July, 9 August, and 14 September 2010, and on 14 March 2011. Leaves were dried at $60^{\circ} \mathrm{C}$ for $48 \mathrm{~h}$, ground to powder using a mill grinder and stored in plastic vials for nutrient quantification. Total nitrogen was determined by the Kjeldahl digestion method [56]. Macro- and micro-nutrients were quantified by atomic absorption after mineralization [57]. Phosphorus was determined colorimetrically as described in Fogg and Wilkinson [58].

\subsection{Data Analysis}

Yield and fruit quality data were compared by two-way analysis of variance (ANOVA) with year and irrigation as main factors, block as replicate factor, and year $\times$ irrigation as the only interaction. Vitamin $C$ and carotenoids were compared by one-way ANOVA with irrigation as the main factor and block as a replicate factor. Leaf nutrients were compared by two-way ANOVA with sampling date and irrigation as the main factors, block as replicate factor, and date $\mathrm{x}$ irrigation as the only interaction. Fruit quality data were not analyzed using crop load or yield as a covariate as any possible difference in fruit number or yield would be due to irrigation treatments. When appropriate, means were separated using Tukey's multiple range test $(p<0.05)$. All described statistical tests were performed using $\mathrm{R}$ procedures (The R Foundation for Statistical Computing, Vienna, Austria). Results were plotted using Sigmaplot (Systat Software Inc., Richmond, CA, USA).

\section{Results and Discussion}

\subsection{Climate, Irrigation Volumes, and Soil and Plant Water Status}

In all five years, evapotranspirative demand was highest during the dry season, i.e., in June, July and August (Figure 1). The rainfall of 2009 was the greatest, although $30 \%$ of annual rainfall was concentrated in January and February, long before the irrigation season started, and $43 \%$ between mid-September and the end of October, after the irrigation season was over (Figure 1). Due to scarce winter rainfall and climate trends in 2008 and 2011, irrigation events started a few days earlier compared to the other seasons (Figure 1). Relevant and frequent precipitations resumed earlier in 2009 than in the other seasons. As a consequence, the 2009 irrigation season was a few days shorter than the other seasons. A five-year average of 360,160, and $163 \mathrm{~mm}$ was applied with CI, PRD and DI, respectively, yielding water savings of about $55-56 \%$ with the deficit irrigation treatments. 


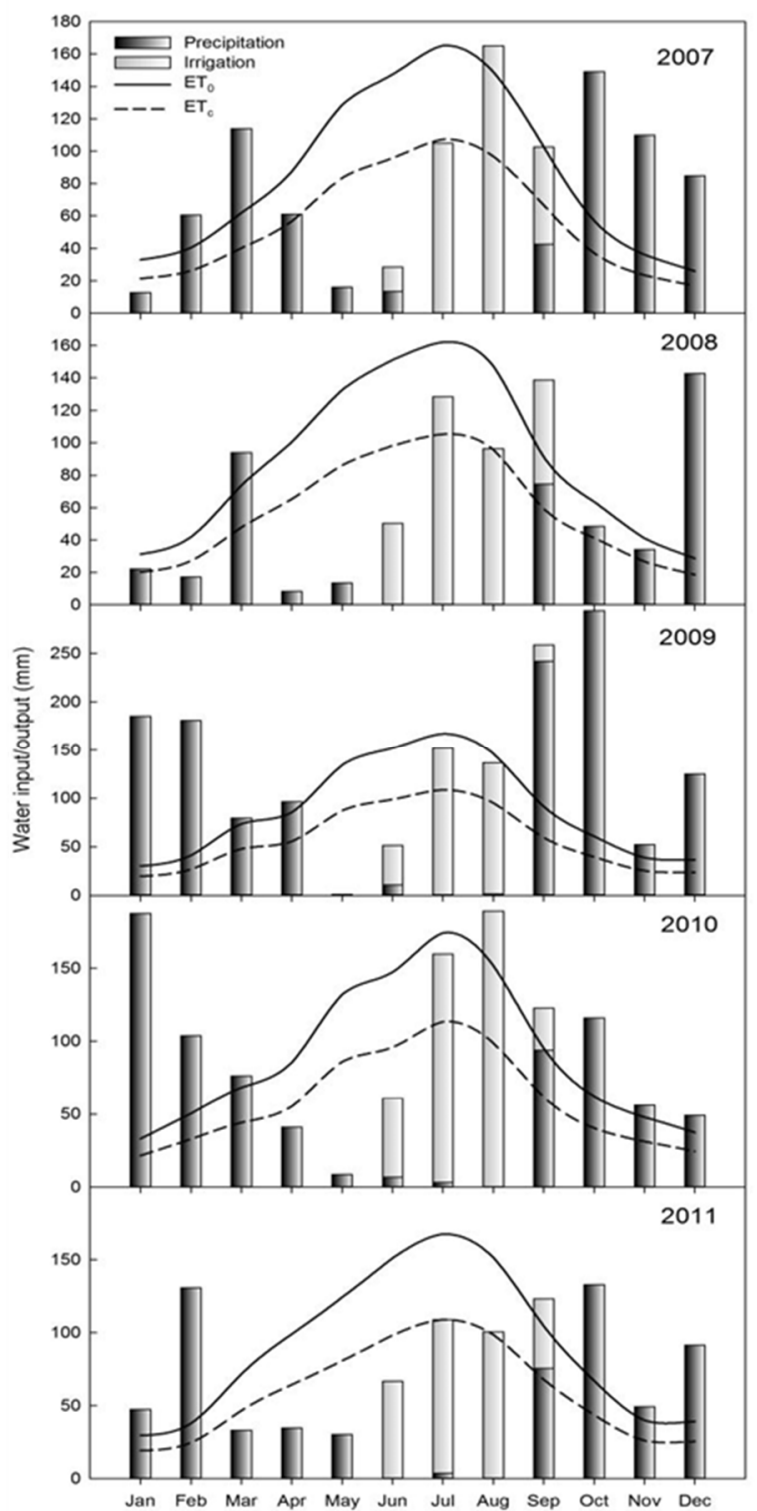

Figure 1. Distribution of total monthly rainfall, irrigation reference $\left(\mathrm{ET}_{0}\right)$ and crop $\left(\mathrm{ET}_{\mathrm{C}}\right)$ evapotranspiration during the five years of observations at the experimental site in Palermo $\left(30^{\circ} 06^{\prime} \mathrm{N}\right.$, $13^{\circ} 21^{\prime} \mathrm{E}$, and $31 \mathrm{~m}$ a.s.1.), Sicily.

Irrigation by the micro-sprinkler system and volumes applied in each event allowed for a good separation of wet and dry sides of the rootzone in PRD and no significant transfer of moisture to the dry side occurred on the days of irrigation. Across the five irrigation seasons, the SWP of the CI treatment showed moderate fluctuations due to wetting and drying cycles between consecutive irrigation events, staying generally above $-50 \mathrm{kPa}$ (about $80 \%$ of field capacity). On the other hand, the SWP of PRD and DI reached negative peak values of over $-180 \mathrm{kPa}$, averaging -75 and $-89 \mathrm{kPa}$, respectively, across the five irrigation seasons.

Average leaf RWC over the five irrigation seasons was 87.5, 85.2, and 83.1 in CI, PRD and DI trees, respectively, indicating an intermediate level of water deficit in PRD trees in between CI and DI trees. The resulting improved water status of PRD trees compared to DI trees may be explained by the changes in tree water use efficiency induced by the drying soil on one portion of the rootzone (i.e., root $\mathrm{ABA}$ and cytokinin synthesis, xylem sap $\mathrm{pH}$ changes, partial stomatal closure, as well as less soil 
wetted surface and water loss by evaporation). More detailed information and considerations about the effects of the same treatments on soil and tree water status were described by Mossad et al. [58].

\subsection{Yield and Fruit Quality}

Yield responses of 'Valencia' trees to irrigation followed similar alternating trends during the years of observations, as indicated by the lack of interaction between year and irrigation (Figure 2). Yield, crop load, yield efficiency and cropping efficiency of 2009 and 2011 were lower than those of 2008, 2010 and 2012. Yield parameters were generally not affected by deficit irrigation, only yield per tree was lower in DI than CI trees (Figure 2A). Interestingly, crop load and especially cropping efficiency were similar in all treatments, including DI. This general lack of irrigation effect agrees with previous observations on drip-irrigated 'Tarocco' [42,59] and navel oranges under PRD [60], and 'Navelina' oranges under DI [25], but is apparently inconsistent with other studies in citrus where yields were reduced by deficit irrigation $[21,23,36,44,61]$.
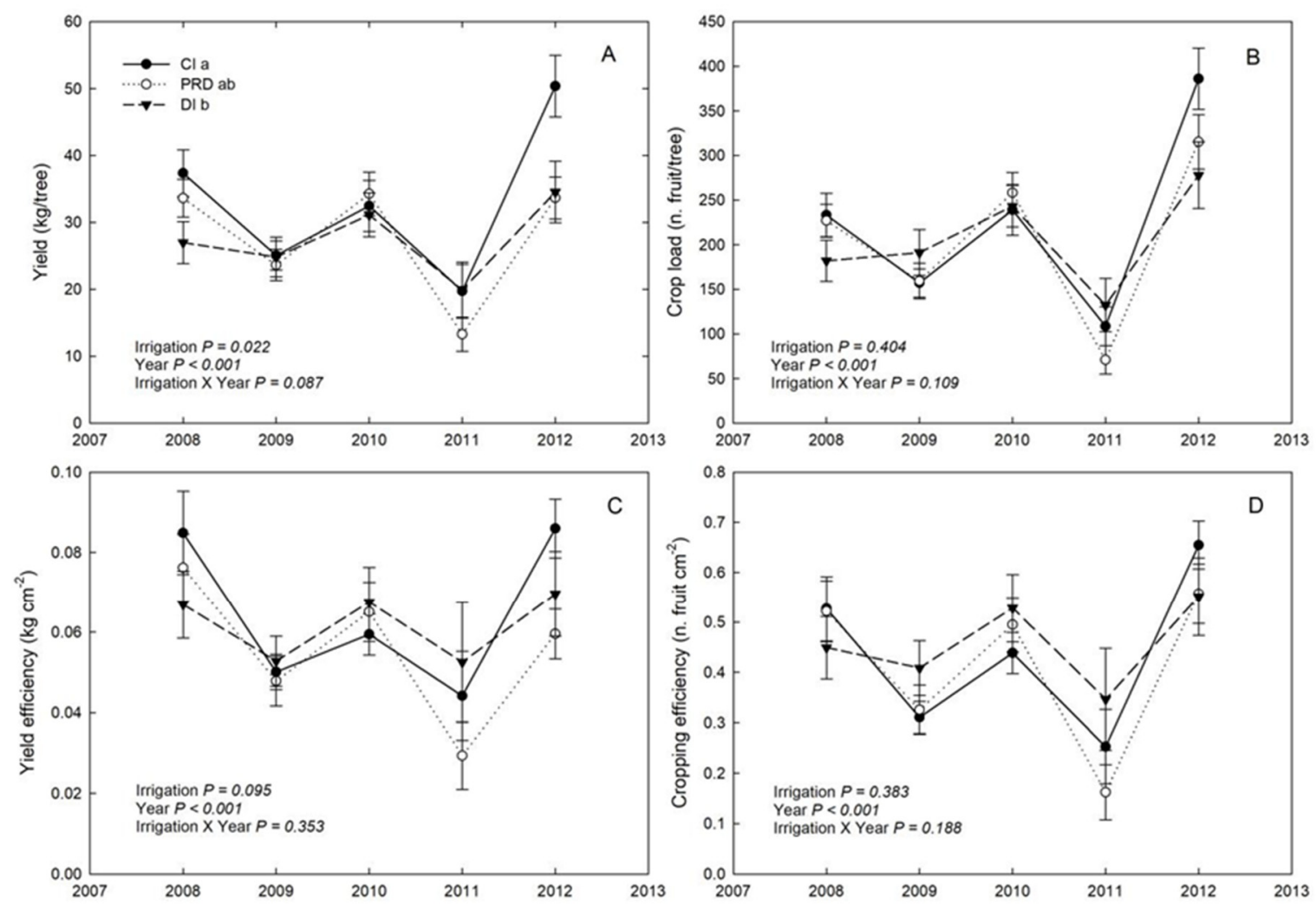

Figure 2. Yield (A), crop load (B), yield efficiency (C), and cropping efficiency (D) of adult 'Valencia' orange trees under conventional irrigation $(\mathrm{CI})$, partial rootzone drying (PRD), and continuous deficit irrigation (DI). Error bars are standard errors of the means. $p$-values in each panel are for main factors and interactions from the ANOVA models. Lower-case letters in panel A indicate significant differences among levels of irrigation (Tukey's multiple range test, $p<0.05$ ).

Fruit weight was generally inversely related to yield per tree across years, and CI fruits were bigger than DI regardless of the year, whereas PRD fruit weight was intermediate (Figure 3A). Indeed, 'Clementina de Nules' yield reductions under deficit irrigation have been associated with either increased fruit drop in the case of early deficit, or reduced fruit size in the case of late deficit [21]. In our 'Valencia' orange trees, DI and PRD strategies induced no significant fruit drop (Figure 2B) and fruit size reductions only in DI trees (Figure 3A). Evidently, fruit size effects are responsible for DI yield reductions, while they were not sufficient to cause significant yield reductions in PRD trees. On the contrary, Treeby et al. [37] reported significant size reductions of navel oranges in response to both 
PRD and reduced irrigation volumes. In addition, Consoli et al. [42] reported fruit size reductions of 'Tarocco' orange in response to PRD. This discrepancy may be in part justified by the fact that the fruit growth period is longer in 'Valencia' (up to 400 days) than in navel or 'Tarocco' oranges and, as a consequence, deficit irrigation was imposed at different growth stages in the three cultivars. In particular, PRD was imposed during mid to late stage II (middle to end of cell enlargement) of fruit growth in the navel and 'Tarocco' oranges, while we imposed PRD at an earlier growth stage of 'Valencia' oranges. Water deficit at final cell enlargement (i.e., 'Tarocco' and navel oranges) has a more direct and marked effect on final fruit size than water deficit at the end of stage I or beginning of stage II (i.e., 'Valencia' oranges). Indeed, our 'Valencia' trees had a longer time under rainy months (fall and winter) than navel or 'Tarocco' oranges to recuperate any possible growth loss before harvest.
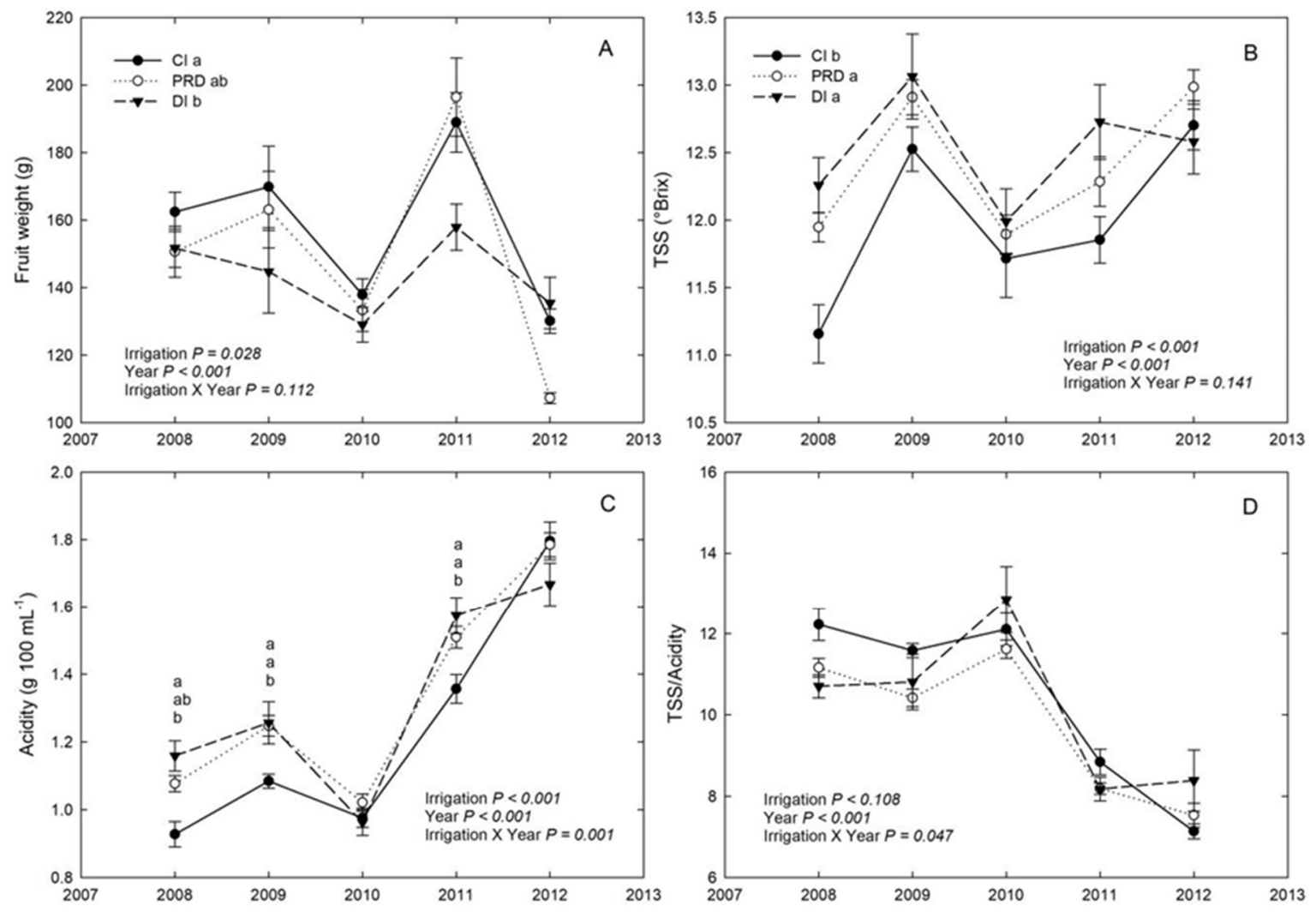

Figure 3. Fruit weight (A), total soluble solids (TSS, B), acidity (C), and TSS to acidity ratio (D) in adult 'Valencia' orange trees under conventional irrigation (CI), partial rootzone drying (PRD), and continuous deficit irrigation (DI) in the five years of observations. Error bars are standard errors of the means. P-values in each panel are for main factors and interactions from the ANOVA models. When present, lower-case letters indicate significant differences among irrigation levels in a specific year (Tukey's multiple range test, $p<0.05$ ). Lower-case letters in panel A and B indicate significant differences among levels of irrigation (Tukey's multiple range test, $p<0.05$ ).

Juice TSS was higher in PRD and DI fruits than in CI fruits, regardless of year (Figure 3B), whereas juice of DI and PRD fruits showed higher TA than juice of CI fruits in all years except for 2010 and 2012 (Figure 3C). Increased juice TSS and TA in response to water deficit is a very well established response in citrus, particularly when water deficit is imposed during the entire season [23] or during mid to late fruit growth $[21,42,44,48-50]$. The sugar acid ratio was generally unaffected by irrigation and lowest in 2011 and 2012 due to TA increases (Figure 3D).

Fruits of DI trees also yielded less juice than fruits of CI trees in 2009 and 2012 (Figure 4A). Similar reductions of juice yield have been reported in 'Tarocco' [62] and 'Lane late' [51] orange under deficit irrigation and are consistent with straight irrigation volume reductions. Although PRD trees 
received the same irrigation volume as DI trees, juice yield of PRD trees was intermediate between CI and DI and not significantly less than the juice yield of CI trees. This may be explained by the fact that PRD trees experienced less water deficit than DI trees, thanks to the irrigation placement effect induced by the PRD technique. Regardless of year, there was no significant irrigation effect on fruit specific weight (Figure 4B) and peel color (Figure 4C), although CI and PRD fruits tended to be better colored than DI fruits. A decrease of peel color in response to PRD or DI has been reported in orange fruits [52,62], suggesting that a certain degree of water deficit during mid to late fruit development stages may either worsen final fruit quality or simply delay fruit maturation.

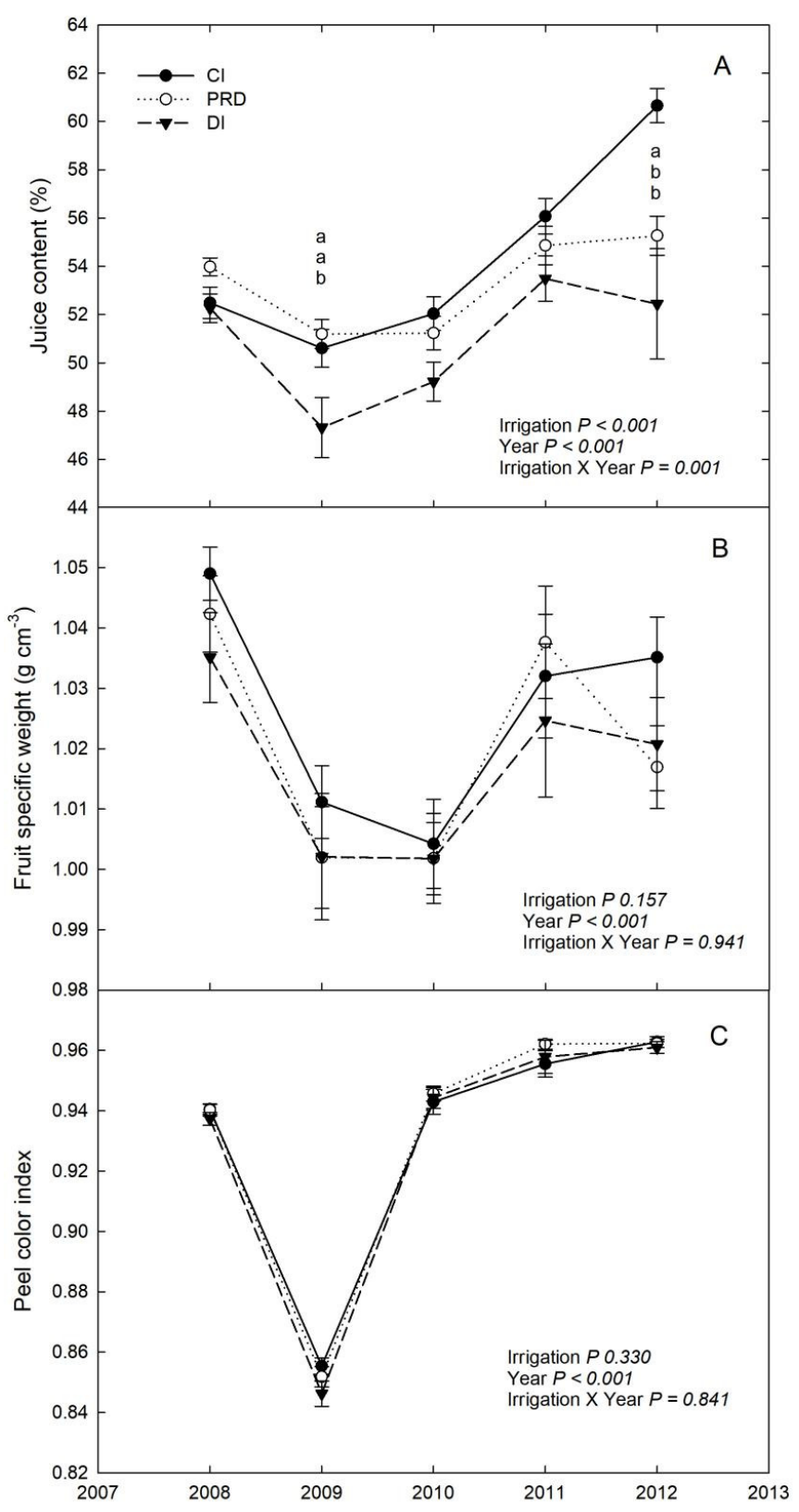

Figure 4. Juice content (A), fruit specific weight (B), and peel color index (C) in adult 'Valencia' orange trees under conventional irrigation (CI), partial rootzone drying (PRD), and continuous deficit irrigation (DI). Error bars are standard errors of the means. P-values in each panel are for main factors and interactions from the ANOVA models. When present, lower-case letters indicate significant differences among irrigation levels in a specific year (Tukey's multiple range test, $p<0.05$ ). 
In 2010, the juice concentration of total carotenoids and vitamin C was higher in DI fruits than in CI fruits, and intermediate in PRD fruits (Table 1). This was not due to fruit dehydration as using percent juice water content as a covariate in the analysis did not cancel differences in carotenoids or vitamin C (data not shown). On the contrary, if total carotenoids and vitamin $C$ were expressed on a per fruit weight basis, those differences were canceled indicating that they were due to differences in fruit and juice yield. Our results agree with those found by Yang et al. [63] in 'Newhall' navel oranges. Other studies have reported no effect of deficit irrigation on vitamin C concentrations [25,62] or even a negative effect of water stress on juice vitamin $C$ in navel oranges [64]. In this case, the discrepancy with our results may be explained by the degree of dehydration experienced by trees and/or the timing of water deficit application with respect to fruit growth stage, water deficit being, in many cases, detrimental at later stages of fruit growth or during maturation.

Table 1. Total carotenoids and vitamin $C$ in juice and fruits of adult 'Valencia' orange trees under conventional irrigation (CI), partial rootzone drying (PRD), and continuous deficit irrigation (DI). Measurements taken only in fruits harvested in 2010. When present, lower-case letters indicate significant differences among irrigation treatments and within each column (Tukey's multiple range test, $p<0.05)$.

\begin{tabular}{|c|c|c|c|c|}
\hline & $\begin{array}{c}\text { Carotenoids } \\
\left(\mathrm{mg} \cdot \mathrm{L}^{-1}\right)\end{array}$ & $\begin{array}{l}\text { Vitamin C } \\
\left(\mathrm{mg} \cdot \mathrm{L}^{-1}\right)\end{array}$ & $\begin{array}{c}\text { Carotenoids } \\
\left(\mathrm{mg} \cdot \mathrm{kg}^{-1}\right)\end{array}$ & $\begin{array}{l}\text { Vitamin C } \\
\left(\mathrm{mg} \cdot \mathrm{kg}^{-1}\right)\end{array}$ \\
\hline $\mathrm{CI}$ & $29.1 \pm 1.26 \mathrm{~b}$ & $362 \pm 5.22 b$ & $15.1 \pm 0.63$ & $188 \pm 7.60$ \\
\hline PRD & $32.3 \pm 1.22 \mathrm{ab}$ & $371 \pm 6.55 \mathrm{ab}$ & $16.5 \pm 0.67$ & $189 \pm 4.43$ \\
\hline DI & $35.8 \pm 1.98 \mathrm{a}$ & $382 \pm 4.76 \mathrm{a}$ & $17.2 \pm 1.20$ & $188 \pm 3.46$ \\
\hline
\end{tabular}

Sugar yield expressed in tons per hectare was similar for all irrigation treatments in all years except 2012, when it was higher in CI than in PRD and DI trees (Figure 5A). This is entirely due to differences in fruit yield rather than TSS. When testing for differences in irrigation water productivity, year and irrigation treatment always interacted. Specifically, from 2008 to 2010, fruit, juice, and sugar production per unit irrigation water were higher in PRD and DI trees than in CI trees (Figure 5B-D). On the other hand, no difference in fruit, juice, or sugar production per unit irrigation water was observed in 2011 and 2012. The latter seems to be explained by a slight increase of fruit and juice yield in CI trees (especially in 2012) rather than to a decline of fruit yield and/or quality by deficit irrigated trees in the last two years of the trial. 

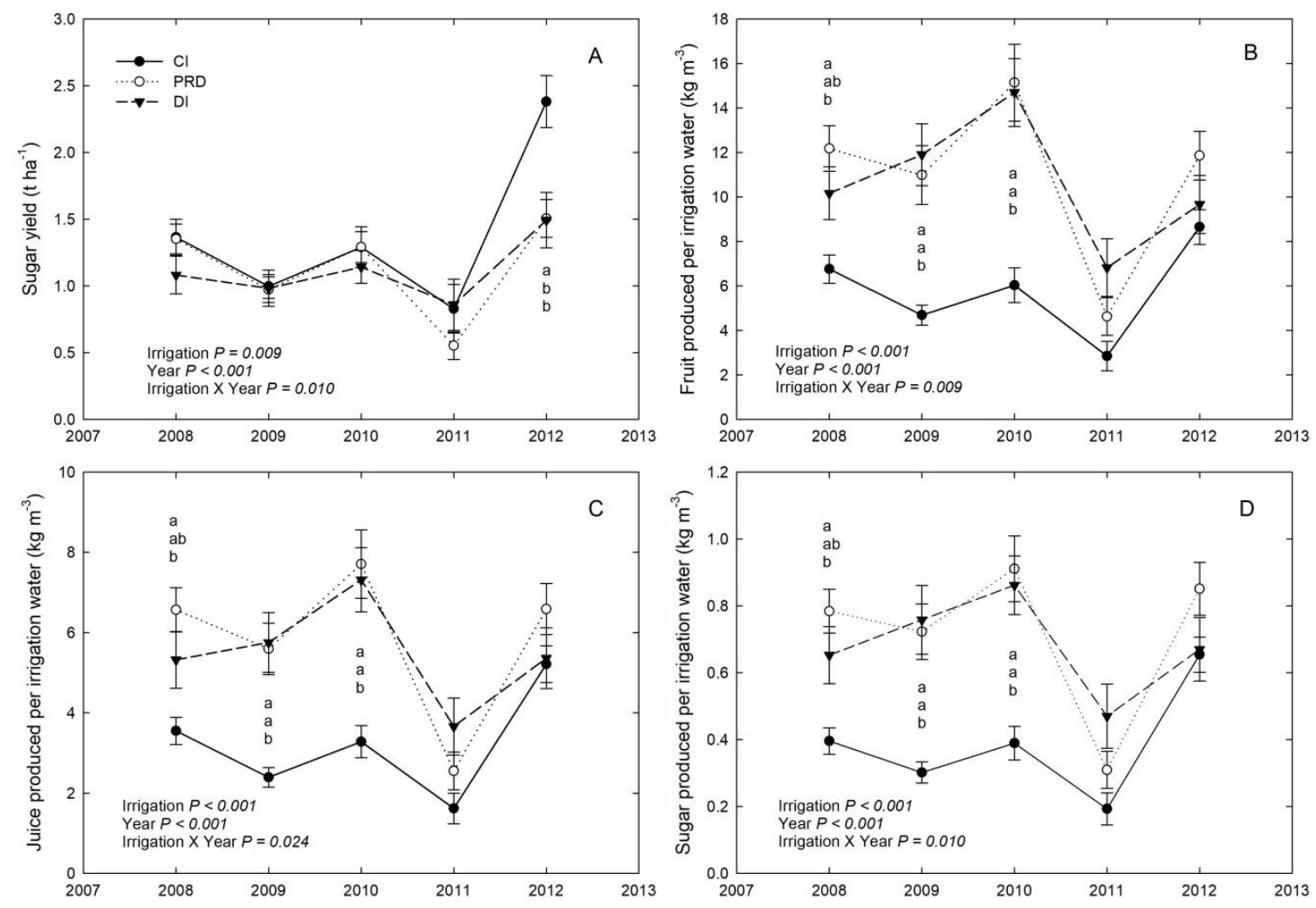

Figure 5. Sugar yield (A) and fruit (B), juice (C), and sugar (D) production per unit of irrigation water in adult 'Valencia' orange trees under conventional irrigation (CI), partial rootzone drying (PRD), and continuous deficit irrigation (DI) in the five years of observations. Error bars are standard errors of the means. $p$-values in each panel are for main factors and interactions from the ANOVA models.

In the 2010-2011 cropping season, leaf $\mathrm{N}$ content was similar in all irrigation treatments at the beginning of the irrigation season (early summer) and right before harvest (April 2011), while it tended to be higher in CI trees than in deficit irrigated trees in August and September (Figure 6A). A similar difference was observed only in July for P (Figure 6B), whereas $\mathrm{K}$ and Ca were higher in CI than in DI trees right before harvest (Figure $6 \mathrm{C}, \mathrm{D}$ ). No significant difference among irrigation treatments was detected for Mg (Figure 6E). 


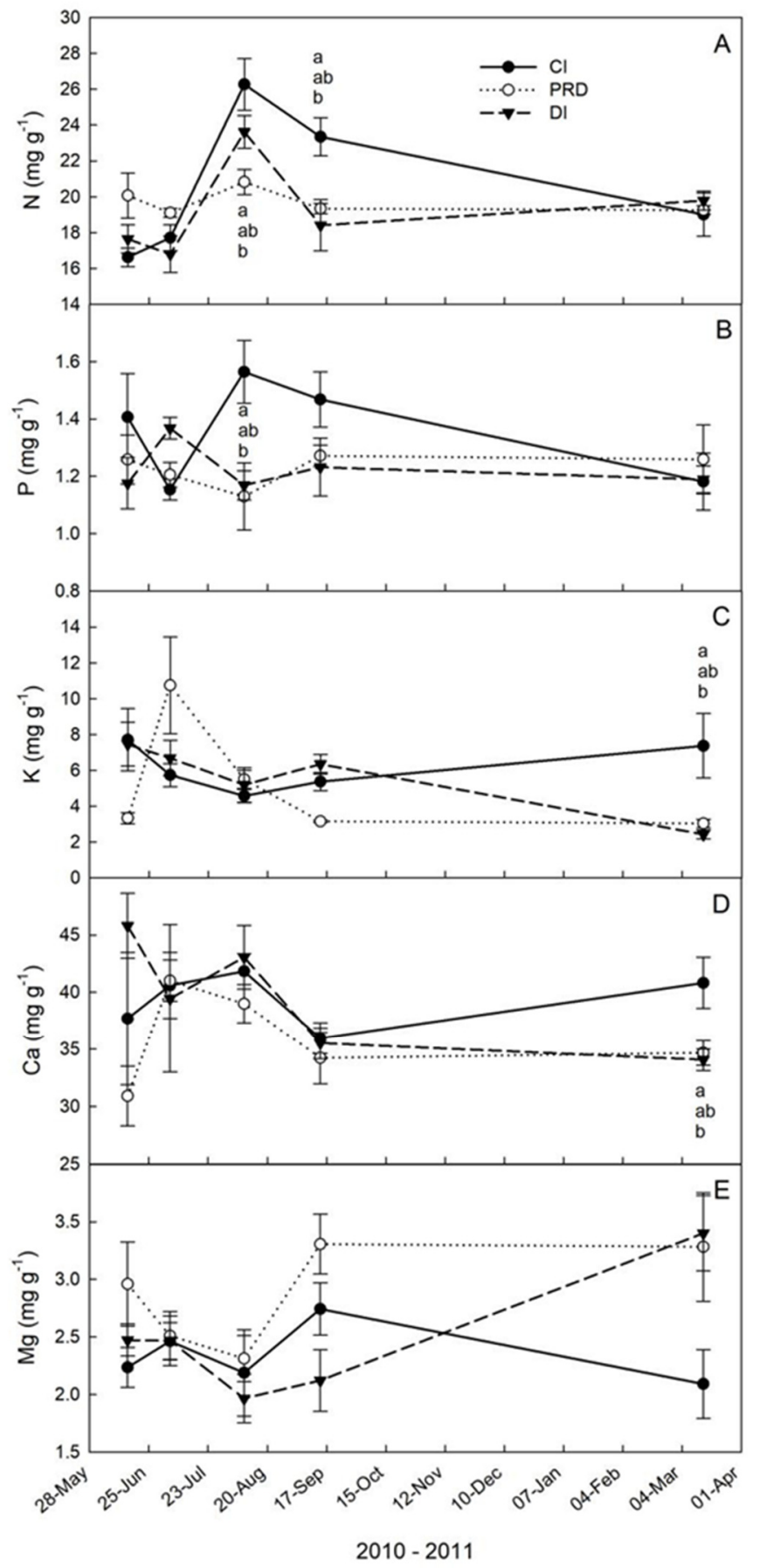

Figure 6. Nitrogen (A), phosphorus (B), potassium (C), calcium (D), and magnesium (E) content in leaves of adult 'Valencia' orange trees under conventional irrigation (CI), partial rootzone drying (PRD), and continuous deficit irrigation (DI) in the 2010-2011 cropping season. Error bars are standard errors of the means. Different letters indicate significant differences by Tukey's multiple range test $(p<0.05)$.

As for leaf micro-nutrients, PRD significantly increased $\mathrm{Na}$ at the beginning and end of the irrigation period, while DI increased $\mathrm{Na}$ only before fruit harvest (Figure 7A). Leaf $\mathrm{Cu}$ was generally decreased by deficit irrigation treatments in July and August (Figure 7B), whereas Fe was increased by PRD in June and August and by DI right before harvest (Figure 7C). No significant effect of irrigation on leaf Mn was detected (Figure 7D). 


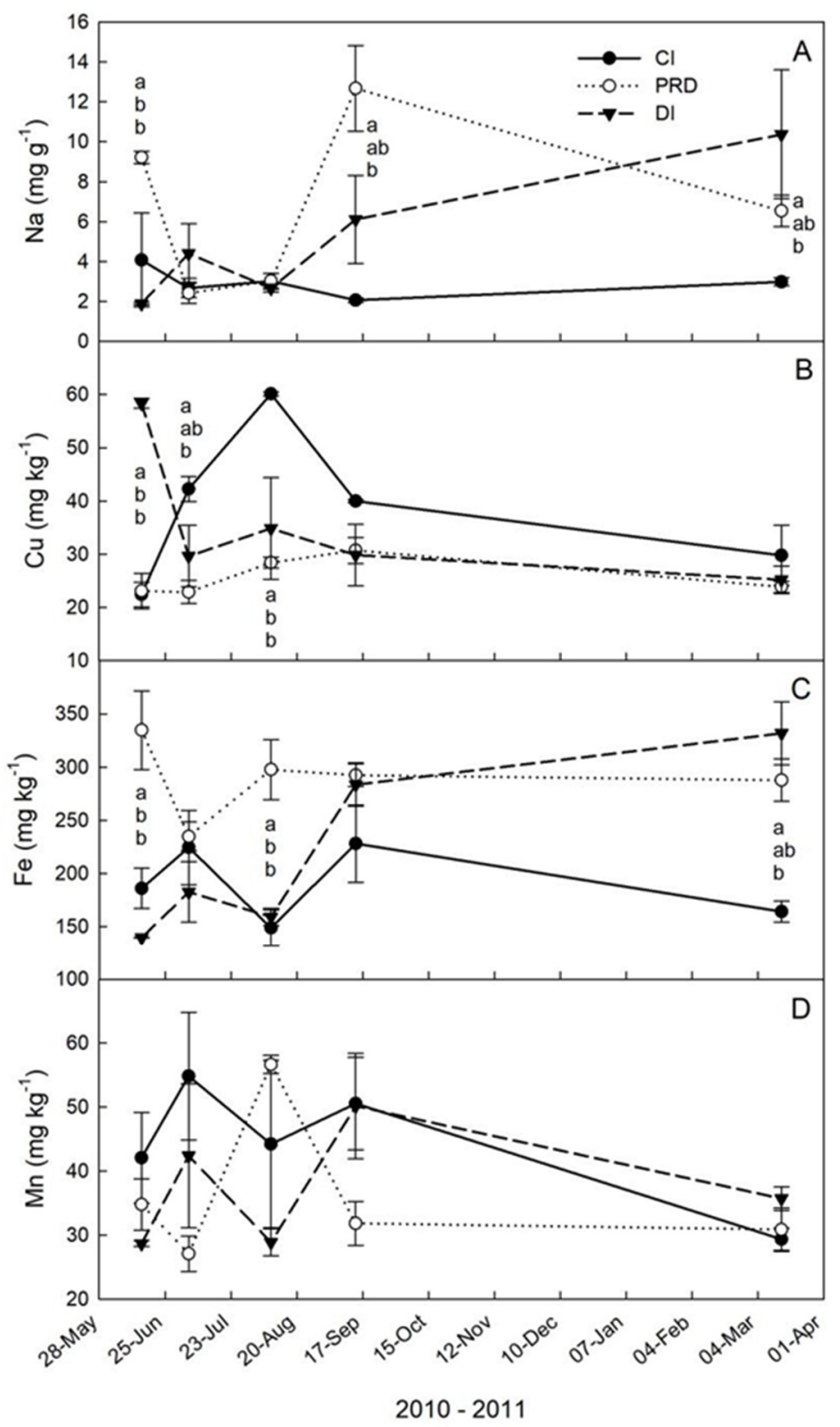

Figure 7. Sodium (A), cupper (B), iron (C), and manganese (D) content in leaves of adult 'Valencia' orange trees under conventional irrigation (CI), partial rootzone drying (PRD), and continuous deficit irrigation (DI) in the 2010-2011 cropping season. Error bars are standard errors of the means. Different letters indicate significant differences by Tukey's multiple range test $(p<0.05)$.

In 'Tarocco' orange, leaf nitrogen content was reduced by DI and PRD, whereas P, K and micronutrients, in most cases, indicated opposite trends [65]. In the Swingle Citrumelo rootstock, total leaf $\mathrm{N}$ and $\mathrm{K}$ contents were not affected by PRD, but increased by DI [66]. In our case, the lack of generalized and consistent nutrient decrease under deficit irrigation may be in part explained, at least for $\mathrm{N}$ and $\mathrm{P}$, by the Birch effect, according to which wetting (for example with fall and winter rainfall) of previously dry soil favors $\mathrm{N}$ and $\mathrm{P}$ release [67]. Another explanation for this lack of consistent differences is the fact that our trees were fertilized in winter with complex solid fertilizers, so the effects of the irrigation volume/placement may become less evident. 


\section{Conclusions}

Overall, our observations show that final yields of 'Valencia' orange trees under the Mediterranean climate of Northern Sicily were only affected by continuous water deficit and not by PRD irrigation. Indeed, the straight reduction of irrigation volumes by $55 \%$ (DI) over conventional irrigation induced an average $4.4 \%$ loss of leaf hydration, causing significant reductions of final fruit size and most importantly an average of $3.4 \%$ reduction of juice yield, corresponding to a loss of over 2.6 tons of juice and about $261 \mathrm{~kg}$ of sugar per hectare and year. On the other hand, water savings of about 2 mega liters per hectare and year with PRD caused a mild 2.3\% leaf dehydration over CI and limited yield losses along with fruit quality improvements. This provides clear evidence of the advantage of adopting a PRD strategy for juice orange production in semi-arid areas. Although the PRD irrigation layout is associated with significantly higher (nearly double) costs of the irrigation system due to doubling of irrigation lines, water savings of about 2 mega liters per hectare along with fruit quality (mainly sugars) improvements may be a viable tradeoff for the higher initial expenses, especially in areas where water is limited and/or expensive to the growers. Indeed, juice oranges are often paid to the growers by the weight and sugar content, and, in a few cases, also by the juice yield.

Yield, juice and sugar losses caused by DI were in part compensated by water savings associated with a $55 \%$ reduction of irrigation volumes. Indeed, important reductions of irrigation volumes $(55 \%$ in DI and 56\% in PRD) at the early cell enlargement stage of 'Valencia' fruit determined significant increases in water use efficiency over CI in both deficit treatments, and specifically in PRD (improved fruit quality) thanks to the irrigation placement effect. This translated into more grams of fruit, juice, or sugars per liter of irrigation water in DI and PRD indicating that withholding water, especially by the PRD technique, may be beneficial to the economy of Mediterranean citrus farmers. Future studies will have to explore in more detail the nutritional status of trees under PRD and deficit irrigation in general, as well as conduct site-specific economic analysis to evaluate where and when applying PRD irrigation strategies at a commercial scale may be viable to growers.

Author Contributions: Conceptualization, R.L.B.; methodology, R.L.B. and V.F.; validation, R.L.B.; formal analysis, R.L.B.; investigation, A.M.; resources, R.L.B. and V.F.; data curation, A.M., R.L.B. and V.F.; writing-original draft preparation, A.M. and R.L.B.; writing — review and editing, R.L.B. and V.F.; visualization, R.L.B.; supervision, R.L.B. and V.F.; project administration, R.L.B.; funding acquisition, R.L.B. All authors have read and agreed to the published version of the manuscript.

Funding: This research was funded by the University of Palermo, grants Ex 60\% Prot. ORPA0792NS 2007 and CORI 2006.

Acknowledgments: We would like to thank Eristanna Palazzolo for the help with leaf nutrient analysis, and Roberto Massenti, Alessio Scalisi and all the other undergraduate students that helped with field operations.

Conflicts of Interest: The authors declare no conflict of interest. The funders had no role in the design of the study; in the collection, analyses, or interpretation of data; in the writing of the manuscript, or in the decision to publish the results.

\section{References}

1. Chalmers, D.J.; Mitchell, P.D.; van Heek, L.A.G. Control of peach tree growth and productivity by regulated water supply, tree density, and summer pruning. J. Am. Soc. Hortic. Sci. 1981, 106, 307-312.

2. Mitchell, P.D.; Chalmers, D.J. The effect of reduced water supply on peach tree growth and yields. J. Am. Soc. Hortic. Sci. 1982, 107, 853-856.

3. Girona, J.; Gelly, M.; Mata, M.; Arbones, A.; Rufat, J.; Marsal, J. Peach tree response to single and combined deficit irrigation regimes in deep soils. Agric. Water Manag. 2005, 72, 97-108. [CrossRef]

4. Marsal, J.; Casadesus, J.; Lopez, G.; Mata, M.; Bellvert, J.; Girona, J. Sustainability of regulated deficit irrigation in a mid-maturing peach cultivar. Irrig. Sci. 2016, 34, 201-208. [CrossRef]

5. Ruiz-Sánchez, M.C.; Abrisqueta, I.; Conejero, W.; Vera, J. Deficit Irrigation Management in Early-Maturing Peach Crop. In Water Scarcity and Sustainable Agriculture in Semiarid Environment; García Tejero, I.F., Durán Zuazo, V.H., Eds.; Academic Press: New York, NY, USA, 2018; pp. 111-129. 
6. Torrecillas, A.; Corell, M.; Galindo, A.; Pérez-López, D.; Memmi, H.; Rodríguez, P.; Cruz, Z.N.; Centeno, A.; Intrigliolo, D.S.; Moriana, A. Agronomical Effects of Deficit Irrigation in Apricot, Peach, and Plum Trees. In Water Scarcity and Sustainable Agriculture in Semiarid Environment; García Tejero, I.F., Durán Zuazo, V.H., Eds.; Academic Press: New York, NY, USA, 2018; pp. 87-109.

7. Caspari, H.W.; Behboudian, M.H.; Chalmers, D.J. Water use, growth, and fruit yield of 'Hosui' Asian pears under deficit irrigation. J. Am. Soc. Hortic. Sci. 1994, 119, 383-388. [CrossRef]

8. Mitchell, P.D.; Van Den Ende, B.; Jerie, P.H.; Chalmers, D.J. Responses of 'Bartlett' pear to withholding irrigation, regulated deficit irrigation, and tree spacing. J. Am. Soc. Hortic. Sci. 1989, 114, 15-19.

9. Wu, Y.; Zhao, Z.; Liu, S.; Huang, X.; Wang, W. Does partial root-zone drying have advantages over regulated deficit irrigation in pear orchard under desert climates? Sci. Hortic. 2020, 262, 109099. [CrossRef]

10. Lampinen, B.D.; Shackel, K.A.; Southwick, S.M.; Olson, B.; Yeager, J.T.; Goldhamer, D. Sensitivity of yield and fruit quality of French prune to water deprivation at different fruit growth stages. J. Am. Soc. Hortic. Sci. 1995, 120, 139-147. [CrossRef]

11. Goldhamer, D.A.; Viveros, M.; Salinas, M. Regulated deficit irrigation in almonds: Effects of variations in applied water and stress timing on yield and yield components. Irrig. Sci. 2006, 24, 101-114. [CrossRef]

12. Lipan, L.; Martín-Palomo, M.J.; Sánchez-Rodríguez, L.; Cano-Lamadrid, M.; Sendra, E.; Hernández, F.; Burló, F.; Vázquez-Araújo, L.; Andreu, L.; Carbonell-Barrachina, Á.A. Almond fruit quality can be improved by means of deficit irrigation strategies. Agric. Water Manag. 2019, 217, 236-242. [CrossRef]

13. Martín-Palomo, M.J.; Corell, M.; Girón, I.; Andreu, L.; Trigo, E.; López-Moreno, Y.E.; Torrecillas, A.; Centeno, A.; Pérez-López, D.; Moriana, A. Limitations of using trunk diameter fluctuations for deficit irrigation scheduling in almond orchards. Agric. Water Manag. 2019, 218, 115-123. [CrossRef]

14. Goldhamer, D.A.; Beede, R.H. Regulated deficit irrigation effects on yield, nut quality and water-use efficiency of mature pistachio trees. J. Hortic. Sci. Biotechnol. 2004, 79, 538-545. [CrossRef]

15. Carbonell-Barrachina, Á.A.; Memmi,H.; Noguera-Artiaga, L.; Gijón-López, M.D.C.; Ciapa, R.; Pérez-López, D. Quality attributes of pistachio nuts as affected by rootstock and deficit irrigation. J. Sci. Food Agric. 2015, 95, 2866-2873. [CrossRef] [PubMed]

16. Noguera-Artiaga, L.; Sánchez-Bravo, P.; Hernández, F.; Burgos-Hernández, A.; Pérez-López, D.; Carbonell-Barrachina, Á.A. Influence of regulated deficit irrigation and rootstock on the functional, nutritional and sensory quality of pistachio nuts. Sci. Hortic. 2020, 261, 108994. [CrossRef]

17. Ruiz-Sànchez, M.C.; Torrecillas, A.; Perez-Pastor, A.; Domingo, R. Regulated deficit irrigation in apricot trees. Acta Hortic. 2000, 537, 759-766. [CrossRef]

18. Goldhamer, D.A. Regulated deficit irrigation for California canning olives. Acta Hortic. 1997, 474, 369-372. [CrossRef]

19. Moriana, A.; Orgaz, F.; Pastor, M.; Fereres, E. Yield responses of mature olive orchard to water deficits. J. Am. Soc. Hortic. Sci. 2003, 123, 425-431. [CrossRef]

20. García, J.M.; Morales-Sillero, A.; Pérez-Rubio, A.G.; Diaz-Espejo, A.; Montero, A.; Fernández, J.E. Virgin olive oil quality of hedgerow 'Arbequina' olive trees under deficit irrigation. J. Sci. Food Agric. 2017, 97, 1018-1026. [CrossRef]

21. González-Altozano, P.; Castel, J.L. Regulated deficit irrigation in 'Clementina de Nules' citrus trees. I. Yield and fruit quality effects. J. Hortic. Sci. Biotechnol. 1999, 74, 706-713. [CrossRef]

22. Pérez-Pérez, J.G.; Romero, P.; Navarro, J.M.; Botía, P. Response of sweet orange cv 'Lane late' to deficit-irrigation strategy in two rootstocks. II: Flowering, fruit growth, yield and fruit quality. Irrig. Sci. 2008, 26, 519-529. [CrossRef]

23. Hutton, R.J.; Loveys, B.R. A partial root zone drying irrigation strategy for citrus-Effects on water use efficiency and fruit characteristics. Agric. Water Manag. 2011, 98, 1485-1496. [CrossRef]

24. García-Tejero, I.; Durán-Zuazo, V.H.; Jiménez-Bocanegra, J.A.; Muriel-Fernández, J.L. Improved water-use efficiency by deficit-irrigation programmes: Implications for saving water in citrus orchards. Sci. Hortic. 2011, 128, 274-282. [CrossRef]

25. Gasque, M.; Martí, P.; Granero, B.; González-Altozano, P. Effects of long-term summer deficit irrigation on 'Navelina' citrus trees. Agric. Water Manag. 2016, 169, 140-147. [CrossRef]

26. Dry, P.R.; Loveys, B.R.; Botting, D.G.; Düring, H. Effects of partial rootzone drying on grapevine vigour, yield, composition of fruit and use of water. In Proceedings of the 9th Australian Wine Industry Technical Conference, Adelaide, Australia, 16-19 July 1995; pp. 128-131. 
27. Dry, P.R.; Loveys, B.R. Factors influencing grapevine vigour and the potential for control with partial rootzone drying. Aust. J. Grape Wine Res. 1998, 4, 140-148. [CrossRef]

28. Gowing, D.J.G.; Davies, W.J.; Jones, H.G. A positive root-sourced signal as an indicator of soil drying in apple, Malus $\times$ domestica Borkh. J. Exp. Bot. 1990, 41, 1535-1540. [CrossRef]

29. Dry, P.R.; Loveys, B.R.; Düring, H. Partial drying of the rootzone of grape. I. Transient changes in shoot growth and gas exchange. Vitis 2000, 39, 3-7.

30. Zhang, J.; Davies, W.J. Increased synthesis of ABA in partially dehydrated root tips and ABA transport from roots to leaves. J. Exp. Bot. 1987, 38, 2015-2023. [CrossRef]

31. Dry, P.R.; Loveys, B.R. Grapevine shoot growth and stomatal conductance are reduced when part of the root system is dried. Vitis 1999, 38, 151-156.

32. Stoll, M.; Loveys, B.; Dry, P. Hormonal changes induced by partial rootzone drying of irrigated grapevine. J. Exp. Bot. 2000, 51, 1627-1634. [CrossRef]

33. Gu, S.; Du, G.; Zoldoske, D.; Hakim, A.; Cochran, R.; Fugelsang, K.; Jorgensen, G. Effects of irrigation amount on water relations, vegetative growth, yield and fruit composition of Sauvignon blanc grapevines under partial rootzone drying and conventional irrigation in the San Joaquin Valley of California, USA. J. Hortic. Sci. Biotechnol. 2004, 79, 26-33. [CrossRef]

34. Wahbi, S.; Wakrim, R.; Aganchich, B.; Tahi, H.; Serraj, R. Effects of partial rootzone drying PRD on adult olive tree Olea europaea in field conditions under arid climate I. Physiological and agronomic responses. Agric. Ecosyst. Environ. 2005, 106, 289-301. [CrossRef]

35. Francaviglia, D.; Farina, V.; Avellone, G.; Lo Bianco, R. Fruit yield and quality responses of apple cvars Gala and Fuji to partial rootzone drying under Mediterranean conditions. J. Agric. Sci. 2013, 151, 556-569. [CrossRef]

36. Eliades, G.; Georgiou, A.; Papadopoulos, I. Effect of conventional irrigation and alternate rootzone drying with sufficient or deficient irrigation water on the production of marsh seedless grapefruit. Agric. Mediterr. 2004, 134, 78-184.

37. Treeby, M.T.; Henriod, R.E.; Bevington, K.B.; Milne, D.J.; Storey, R. Irrigation management and rootstock effects on navel orange [Citrus sinensis (L.) Osbeck] fruit quality. Agric. Water Manag. 2007, 91, 24-32. [CrossRef]

38. Faber, B.A.; Lovatt, C.J. Effects of applying less water by partial root zone drying versus conventional irrigation on navel orange yield. Acta Hortic. 2014, 1038, 523-530. [CrossRef]

39. Goldhamer, D.A.; Salinas, M. Evaluation of regulated deficit irrigation on mature orange trees grown under high evaporative demand. In Proceedings of the IX Congress International Society Citriculture, Orlando, FL, USA, 3-7 December 2000; Volume 1, pp. 227-231.

40. Pérez-Pérez, J.G.; Dodd, I.C.; Botía, P. Partial rootzone drying increases water-use efficiency of lemon Fino 49 trees independently of root-to-shoot ABA signalling. Funct. Plant Biol. 2012, 39, 366-378. [CrossRef]

41. Kusakabe, A.; Contreras-Barragan, B.A.; Simpson, C.R.; Enciso, J.M.; Nelson, S.D.; Melgar, J.C. Application of partial rootzone drying to improve irrigation water use efficiency in grapefruit trees. Agric. Water Manag. 2016, 178, 66-75. [CrossRef]

42. Consoli, S.; Stagno, F.; Vanella, D.; Boaga, J.; Cassiani, G.; Roccuzzo, G. Partial root-zone drying irrigation in orange orchards: Effects on water use and crop production characteristics. Eur. J. Agron. 2017, 82, 190-202. [CrossRef]

43. Shalhevet, J.; Levy, Y. Citrus trees. In Irrigation of Agricultural Crops; Stewart, A., Nielsen, D.R., Eds.; American Society of Agronomy, Inc.: Madison, WI, USA, 1990; pp. 951-986.

44. García-Tejero, I.; Romero-Vicente, R.; Jiménez-Bocanegra, J.A.; Martínez-García, G.; Durán-Zuazo, V.H.; Muriel-Fernández, J.L. Response of citrus trees to deficit irrigation during different phenological periods in relation to yield, fruit quality, and water productivity. Agric. Water Manag. 2010, 97, 689-699. [CrossRef]

45. Navarro, J.M.; Pérez-Pérez, J.G.; Romero, P.; Botía, P. Analysis of the changes in quality in mandarin fruit, produced by deficit irrigation treatments. Food Chem. 2010, 119, 1591-1596. [CrossRef]

46. Grilo, F.S.; Scalisi, A.; Pernice, F.; Morandi, B.; Lo Bianco, R. Recurrent deficit irrigation and fruit harvest affect tree water relations and fruitlet growth in 'Valencia' orange. Eur. J. Hortic. Sci. 2019, 84, 177-187. [CrossRef]

47. Torrecillas, A.; Ruiz-Sánchez, M.C.; Domingo, R.; Hernández-Borroto, J. Regulated deficit irrigation on Fino lemon trees. Acta Hortic. 1993, 33, 205-212. [CrossRef] 
48. Castel, J.R.; Buj, A. Response of Salustiana oranges to high frequency deficit irrigation. Irrig. Sci. 1990, 11, 121-127. [CrossRef]

49. Peng, Y.H.; Rabe, E. Effect of differing irrigation regimes on fruit quality, yield, fruit size and net $\mathrm{CO}_{2}$ assimilation of 'Mihowase' satsuma. J. Hortic. Sci. Biotechnol. 1998, 73, 229-234. [CrossRef]

50. Hutton, R.J.; Landsberg, J.J.; Sutton, B.G. Timing irrigation to suit citrus phenology: A means of reducing water use without compromising fruit yield and quality? Aust. J. Exp. Agric. 2007, 47, 71-80. [CrossRef]

51. Pérez-Pérez, J.G.; Robles, J.M.; Botía, P. Influence of deficit irrigation in phase III of fruit growth on fruit quality in 'Lane late' sweet orange. Agric. Water Manag. 2009, 96, 969-974. [CrossRef]

52. Grilo, F.S.; Di Stefano, V.; Lo Bianco, R. Deficit irrigation and maturation stage influence quality and flavonoid composition of 'Valencia' orange fruit. J. Sci. Food Agric. 2017, 97, 1904-1909. [CrossRef]

53. Mossad, A.; Scalisi, A.; Lo Bianco, R. Growth and water relations of field-grown 'Valencia' orange trees under long-term partial rootzone drying. Irrig. Sci. 2018, 36, 9-24. [CrossRef]

54. Allen, R.G.; Pereira, L.S.; Raes, D.; Smith, M. Crop Evapotranspiration-Guidelines for Computing Crop Water Requirements; FAO Irrigation and Drainage Paper 56; FAO: Rome, Italy, 1998.

55. Arena, E.; Fallico, B.; Maccarone, E. Influence of carotenoids and pulps on the color modification of blood orange juice. J. Food Sci. 2000, 45, 458-460. [CrossRef]

56. Eastin, E.F. Total nitrogen determination for plant material containing nitrate. Anal. Biochem. 1978, 85, 591-594. [CrossRef]

57. Morard, P.; Gullo, J.L. Mineralization des tissus vegetaux en vue du dosage de P, K, Ca, Mg, Na. Ann. Agron. 1970, 21, 229-236.

58. Fogg, D.N.; Wilkinson, N.T. The calorimetric determination of phosphorus. Analyst 1958, 83, 406-414. [CrossRef]

59. Puglisi, I.; Nicolosi, E.; Vanella, D.; Piero, A.R.L.; Stagno, F.; Saitta, D.; Roccuzzo, G.; Consoli, S.; Baglieri, A. Physiological and Biochemical Responses of Orange Trees to Different Deficit Irrigation Regimes. Plants 2019, 8, 423. [CrossRef] [PubMed]

60. Dzikiti, S.; Steppe, K.; Lemeur, R. Partial rootzone drying of drip irrigated 'Navel' orange trees [Citrus sinensis (L.) Osbeck] under semi-arid tropical conditions. Acta Hortic. 2008, 792, 249-256. [CrossRef]

61. García-Tejero, I.; Durán-Zuazo, V.H.; Arriaga-Sevilla, J.; Muriel-Fernández, J.L. Impact of water stress on citrus yield. Agron. Sustain. Dev. 2012, 32, 651-659. [CrossRef]

62. Consoli, S.; Stagno, F.; Roccuzzo, G.; Cirelli, G.L.; Intrigliolo, F. Sustainable management of limited water resources in a young orange orchard. Agric. Water Manag. 2014, 132, 60-68. [CrossRef]

63. Yang, Q.; Wang, Y.; Jia, X.M.; Zheng, Y.Q.; He, S.L.; Deng, L.; Ma, Y.Y.; Xie, R.J.; Yi, S.L.; Lv, Q. Fruit yield and quality response of Newhall navel orange to different irrigation regimes and ground cover in Chongqing Three Gorges Reservoir area. Sci. Hortic. 2018, 241, 57-64. [CrossRef]

64. El-Tanany, M.M.; Sallam, A.A.; Sayed, M.A. Washington Navel orange productivity as affected by deficit irrigation water and potassium application. Middle East J. Appl. Sci. 2019, 902, 370-385.

65. Roccuzzo, G.; Stagno, F.; Ferlito, F.; Intrigliolo, F.; Cirelli, G.L.; Consoli, S. Deficit irrigation for enhancing 'Tarocco' orange fruit quality. Acta Hortic. 2016, 1112, 179-186. [CrossRef]

66. Melgar, J.C.; Dunlop, J.M.; Syvertsen, J.P. Growth and physiological responses of the citrus rootstock Swingle citrumelo seedlings to partial rootzone drying and deficit irrigation. J. Agric. Sci. 2010, 148, 593-602. [CrossRef]

67. Dodd, I.C.; Puértolas, J.; Huber, K.; Pérez-Pérez, J.G.; Wright, H.R.; Blackwell, M.S.A. The importance of soil drying and re-wetting in crop phytohormonal and nutritional responses to deficit irrigation. J. Exp. Bot. 2015, 66, 2239-2252. [CrossRef] [PubMed]

(C) 2020 by the authors. Licensee MDPI, Basel, Switzerland. This article is an open access article distributed under the terms and conditions of the Creative Commons Attribution (CC BY) license (http://creativecommons.org/licenses/by/4.0/). 